\title{
The Prospect of Renewable Energy Resources in Bangladesh: A Study to Achieve the National Power Demand
}

\author{
Shariful Islam Sharif, Md. Anisur Rahman Anik, Md. Al-Amin, Md. Abu Bakr Siddique* \\ Dept. of EEE, IUBAT-Intl. Uni. of Bus. Agri. and Tech., Uttara Model Town, Dhaka, Bangladesh
}

\begin{abstract}
This paper reviews the prospects of available renewable energy resources along with various private and government future project plans to incorporate renewable energy sources and their potentials as per context of Bangladesh. According to the approved renewable energy policy, the Government of Bangladesh (GOB) is devoted to facilitating investment in both public and private sectors in renewable energy projects to substitute contemporaneous non-renewable energy resources and to escalate the contributions of renewable energy based electricity generation. A plan has been initiated by the GOB to generate 5\% of the total energy from renewable energy resources within 2015 and $20 \%$ by the year 2020. The aim of this paper is to provide an overview of the present condition of renewable energy resources in Bangladesh and hence, different types of renewable energies are discussed from global perspective to achieve a clear perception about solving the power crisis issues in Bangladesh with this sustainable approach.
\end{abstract}

Keywords Renewable energy, Power sector, Solar energy, Biomass energy, Biogas energy, Wind energy, Hydro energy, Government, Resources

\section{Introduction}

Renewable energy is energy that is obtained from renewable resources, which are naturally restocked on a human timescale, such as sunlight, wind, rain, tides, waves and geothermal heat. The present renewable energy arrives from biogas, hydro power, solar and wind. Bangladesh is a developing country which offers many options and opportunities for utilizing renewable energy sources for generating electric power. In Bangladesh there are many natural resources such as coal, gas and petroleum. The main source of energy in Bangladesh is natural gas (24\%) which is likely to be depleted by the year 2020 [1]. The government issued its prospect and policy assertion in February 2000, with the plan to provide electricity service to the entire country by the year 2020. At present, total electricity generation capacity is 15,351 MW as of February 2017 (ES in Bangladesh) and this energy sector is increasing day by day. To meet the cumulative demand of electricity coal, gas, diesel, etc. based power generation methods are being used. However, this is not sufficient. The government and non-government organizations are working both independently and jointly to promulgate renewable energy

* Corresponding author:

absiddique@iubat.edu (Md. Abu Bakr Siddique)

Published online at http://journal.sapub.org/ep

Copyright (C) 2018 Scientific \& Academic Publishing. All Rights Reserved technologies (RET) throughout the nation as reported in the extant literature. Therefore, prospective planning and comprehensive understanding of this dynamic field require continuous assessment. Moreover, the progression, as well as regressions, in this sector should be continually scrutinized. In this paper, the present scenario of electricity generation and renewable energy sources in Bangladesh is discussed in detail.

\section{Present Electricity Generation Situation in Bangladesh}

Power generation capacity has increased from 4,942 MW in 2009 to $13,883 \mathrm{MW}$ in 2015 [2].

Table 1 below summarizes the power sector capabilities and distribution in the nation [3].

Table 1. Power Sector Details in Bangladesh

\begin{tabular}{|c|c|}
\hline Item & September, 2016 \\
\hline Power Generation Capacity & $15,755 \mathrm{MW}$ \\
\hline Transmission Line & 10,436 circuit km \\
\hline Distribution Line & $341,000 \mathrm{~km}$ \\
\hline Access to Electricity & $77 \%$ \\
\hline Per Capita Power Generation & $371 \mathrm{kWh}$ \\
\hline Nos. of consumers & $25,26,594$ \\
\hline Average System Loss & $14 \%$ \\
\hline
\end{tabular}


As part of this strategy to increase electricity production, a Power System Master Plan was drawn up in 2010 with the following goals as summarized in table 2 [2].

Table 2. Power System Master Plan

\begin{tabular}{|c|c|}
\hline Year & MW \\
\hline 2016 & 16,000 \\
\hline 2021 & 24,000 \\
\hline 2030 & 40,000 \\
\hline
\end{tabular}

Total electricity consumption is projected to increase to 132 TWh by 2035 in Bangladesh [4].

The government has set a target to generate 2000, MW of electrical power from renewable energy by 2021. Currently, the total electricity generation from such sources is $404 \mathrm{MW}$. The new target of renewable energy would be $10 \%$ of the total electricity generation in 2021 and would increase to $20 \%$ percent by 2030 . Initiatives have been taken to produce $30 \mathrm{MW}$ power from renewable energy from Dhaka, $60 \mathrm{MW}$ from Rangunia, 3 MW from Sharishabari, 55 MW from Gangachhara, $200 \mathrm{MW}$ from Mymensingh, $20 \mathrm{MW}$ from Cox's Bazar and $200 \mathrm{MW}$ from Sun Edition Solar project at Teknaf. In addition, processes are underway to install Solar Home Systems (SHSs) at Kaptai, Hatia, Thakurgaon, Ishwardi and Sirajganj [5].

\section{Renewable Energy Prospects in Bangladesh}

Commendable progression has been compiled in the renewable energy sector in the last few years. At present, $404 \mathrm{MW}$ is being generated from renewable energy sources. Solar home system is a success story in Bangladesh and day by day its popularity is increasing in the rural areas, especially in the off-grid regions. Table 3 below shows the progression complied so far in the renewable energy sector in Bangladesh [2].

Table 3. Progress in the Renewable Energy Sector

\begin{tabular}{|l|c|}
\hline \multicolumn{1}{|c|}{ Methods } & MW \\
\hline Installation of Solar Home System (3.5 million) & 150.00 \\
\hline $\begin{array}{l}\text { Installation of Rooftop Photovoltaic (PV) at } \\
\text { Government/Semi-Government offices }\end{array}$ & 3.00 \\
\hline $\begin{array}{l}\text { Installation of PVs on commercial buildings and shopping } \\
\text { centers }\end{array}$ & 1.00 \\
\hline $\begin{array}{l}\text { Installation of PVs by consumer during new electricity } \\
\text { connections }\end{array}$ & 11.00 \\
\hline Installation of Wind-based power plants & 2.00 \\
\hline Installation of Biomass-based power plants & 1.00 \\
\hline Installation of Biogas- based power plants & 5.00 \\
\hline Solar Irrigation & 1.00 \\
\hline Hydro Electric power generation & 230.00 \\
\hline \multicolumn{1}{|c|}{ Total } & 404.00 \\
\hline
\end{tabular}

\section{Renewable Energy Sources in Bangladesh}

The prospect of renewable energy in Bangladesh is very promising, especially in the case of solar energy. However, for the near future, renewable energy will remain annexed to the current energy genesis by non-renewable conventional means. Still, renewable energy will play an important role reaching consumers outside the national grid or in places where grid connection is delayed. Major sources of renewable energy in Bangladesh are as follows:

\subsection{Solar}

Bangladesh is a south Asian country located in between latitudes $20^{\circ} 34^{\prime}$ and $26^{\circ} 39^{\prime}$ north and longitudes $80^{\circ} 00^{\prime}$ and $90^{\circ} 41^{\prime}$ east. Therefore, it is an ideal location for solar energy utilization. Also, as it is a subtropical country, $70 \%$ of the year sunlight is plentiful [6]. This makes the use of solar panels very effective in Bangladesh. Daily solar radiation is $4-6.5 \mathrm{kWh} / \mathrm{m}^{2}$ and maximum radiation is generally received in the months of March-April and minimum in December-January. Hence, solar energy can be a viable solution for the power crisis in Bangladesh [7].

Also solar energy offers some key qualities like having no waste and emission, resulting no adverse effects on the environment and ideally suited for distributed resource applications [8]. The government has recently taken many steps to address this fact. Concurrently, some Non-government Organization (NGO) is working to provide solar panels to consumers and the price of these panels, at present, is very affordable.

Figure 1 below shows the approximate distribution of SHSs installation division wise and illuminates that the distribution of the SHSs is highest in Dhaka district and lowest in Sylhet district [9].

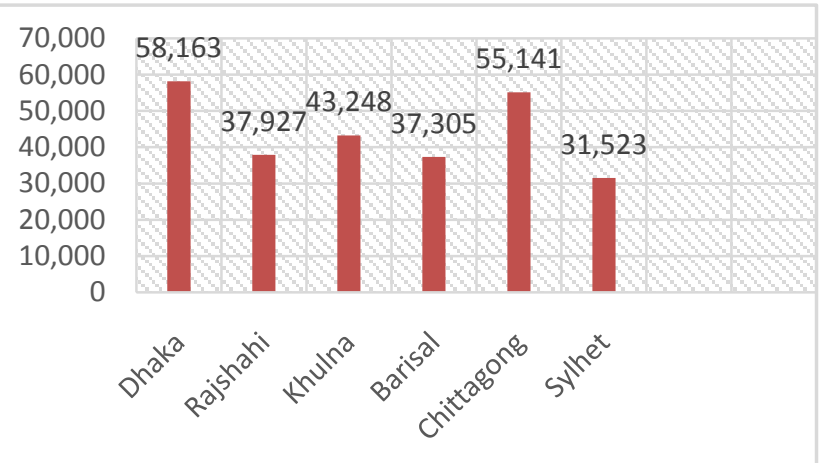

Figure 1. Future Prospect of Solar Energy in Bangladesh

\subsection{Wind Power}

Wind power is the conversion of wind energy by wind turbines into a useful form, such as electrical or mechanical energy. The power is directly proportional to the velocity of the wind. The lengthy period wind flux, particularly in the islands and southern maritime facial of Bangladesh, announce that the average wind speed remains between 3 
and $4.5 \mathrm{~m} / \mathrm{s}$ in the months of March to September and 1.7 to $2.3 \mathrm{~m} / \mathrm{s}$ for the residual period of the year [2]. So, in islands and coastal areas the appeal of wind mills for pumping and electrification is very high. Bangladesh Power Development Board (BPDB) has completed a $1000 \mathrm{~kW}$ capacity wind battery hybrid power project in Kutubdia islands [10]. Under this project, a total of 50 units of $20 \mathrm{~kW}$ capacity stand-alone type wind turbines are being installed. The total power generated by all the wind turbines is stored in a battery bank. Wind Battery Hybrid Power Plant (WBHPP) was officially started on March $30^{\text {th }}$, 2008. The other project of BPDB has completed a 0.90 MW capacity grid connected to wind energy at Muhuri Dam area in Feni district in 2004 [11]. The BPDB has allotted that wind energy can contribute up to $10 \%$ of the energy generated. One major benefit of wind turbines is that they do not need any fuel for electricity generation. Table 4 below shows the feasibility of wind condition for generation of electricity at different places in Bangladesh and illuminates that maximum annual average wind speed is $2.42 \mathrm{~m} / \mathrm{s}$ in Cox's Bazaar and minimum $2.08 \mathrm{~m} / \mathrm{s}$ in Hatia Island [12].

Maximum wind velocity is $5.98 \mathrm{~m} / \mathrm{s}$ in the month of August in Kuakata and the minimum wind velocity is $1.20 \mathrm{~m} / \mathrm{s}$ in the month of December in Reuzan. Wind power is calculated from the following equation:

$$
\mathrm{P}=(1 / 2) \times \rho \times \mathrm{A} \times \mathrm{V}^{3} \text { (in watts) }
$$

Where,

$\mathrm{A}=$ Area perpendicular to the direction of wind flow (in $\mathrm{m}^{2}$ )

$\mathrm{V}=$ Wind velocity $\left(\mathrm{ms}^{-1}\right)$

$\mathrm{P}=$ Power generation (Watts)
Table 4. Feasibility of Wind Condition for Generation of Electricity at Different Places in Bangladesh

\begin{tabular}{|c|c|c|}
\hline Site & $\begin{array}{c}\text { Reference Height } \\
(\mathrm{m})\end{array}$ & $\begin{array}{c}\text { Annual-Average } \\
\text { Wind Speed }(\mathrm{m} / \mathrm{s})\end{array}$ \\
\hline Cox's Bazaar & 10 & 2.42 \\
\hline Sandip Island & 5 & 2.16 \\
\hline Teknaf & 5 & 2.16 \\
\hline Patenga Airport & 5 & 2.45 \\
\hline Comilla Airport & 6 & 2.21 \\
\hline Khepupara & 10 & 2.36 \\
\hline Kutubdia Island & 6 & 2.09 \\
\hline Bhola Island & 7 & 2.44 \\
\hline Hatia Island & 6 & 2.08 \\
\hline
\end{tabular}

\subsection{Biomass Energy}

As an agricultural country, Bangladesh possesses the potential for power generation from biomass sources. Cattle dung, agricultural relic, poultry droppings, water hyacinth, rice husks etc. are available in Bangladesh for biomass power generation. Common biomass resources are rice husk, crop residue, wood, jute stick, animal waste, municipal waste, sugarcane biogases etc. At present, countrywide there are 25,000 biogas plants and over 0.20 million ameliorate ovens have been installed to save biomass fuel. More than 900 briquetting machines have been operating in the country on commercial basis [13]. The energy content of rice chaff is approximated to be about $16 \mathrm{MJ} / \mathrm{kg}$. The biomass plant has a heat rate of $13,648 \mathrm{btu} / \mathrm{kWh}$. The potential results are shown in table 5 [14].

Table 5. Biomass Technical Potential

\begin{tabular}{|c|c|c|c|c|c|}
\hline $\begin{array}{c}\text { Annual Rice } \\
\text { Husk Crop } \\
\text { (tons) }\end{array}$ & $\begin{array}{c}\text { HHV } \\
(\mathrm{MJ} / \mathrm{kg})\end{array}$ & $\begin{array}{c}\text { Gross Energy } \\
\text { Potential } \\
(\mathrm{mmBTU})\end{array}$ & $\begin{array}{c}\text { Gross Electricity } \\
\text { Potential } \\
(\mathrm{MWh})\end{array}$ & $\begin{array}{c}\text { Net Electricity } \\
\text { Potential } \\
(\mathrm{MWh})\end{array}$ & $\begin{array}{c}\text { Potential } \\
\text { Capacity } \\
\text { (MW) }\end{array}$ \\
\hline $10,130,000$ & 16 & $139,363,715$ & $4,084,514$ & $2,042,258$ & 274 \\
\hline
\end{tabular}

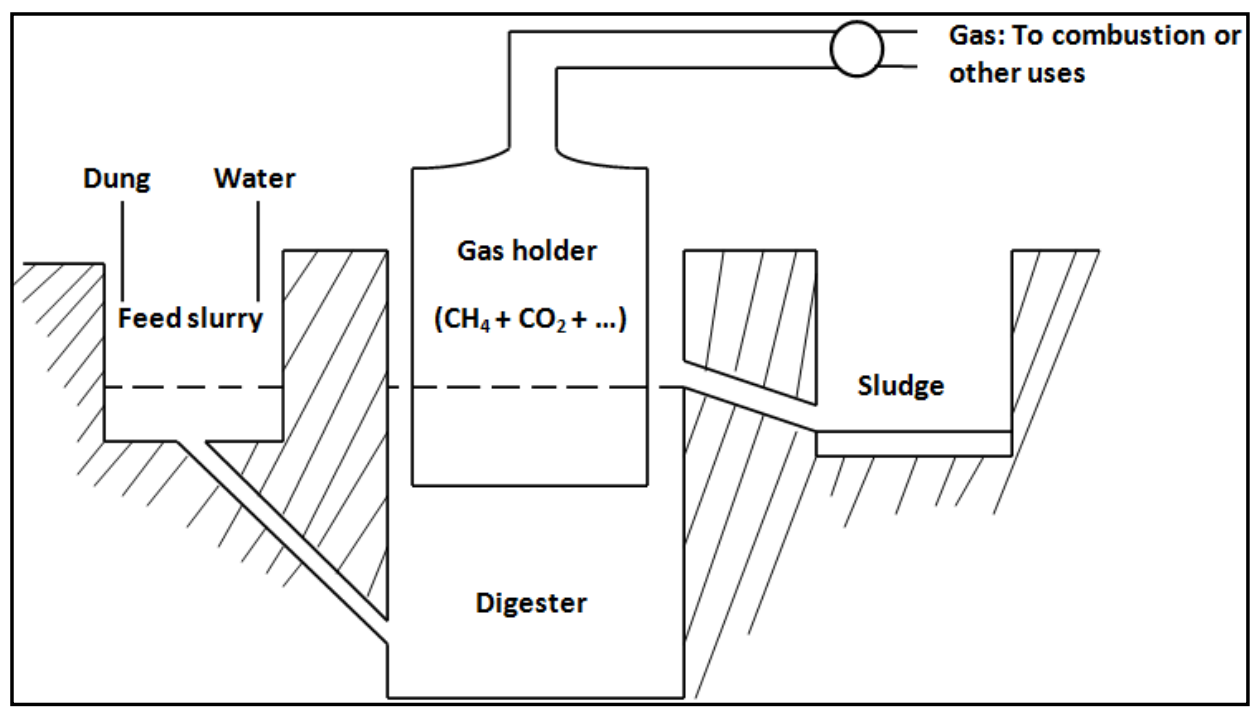

Figure 2. Construction of a Typical Biogas Plant 


\subsection{Biogas Energy}

Biogas is a mixture of gases which is produced by the biological breakdown of organic matter and it occurs in the absence of Oxygen. Dead plant and animal material are organic wastes. In addition, animal dung and kitchen waste can be converted into a gaseous fuel called biogas.

Therefore biogas is a type of bio-fuel. The main elements of biogas are $40-70 \%$ methane $\left(\mathrm{CH}_{4}\right), 30-60 \%$ carbon dioxide $\left(\mathrm{CO}_{2}\right)$ and other gases 1-5\% [15]. It also contains several trace gases. Figure 2 shows a biogas based electricity generation system consists of a digester, a biogas collection tank, a generator as well as the piping and controls required for successful operation.

Grameen Shakti is one of the well renowned NGOs which is a major player in the field of biogas generation in Bangladesh. They have completed 13,500 biogas plants.

At present, Seed Bangla Foundation has proposed a $25 \mathrm{~kW}$ biogas based power plant in Rajshahi [2]. Infrastructure Development Company Limited (IDCOL), a government owned investment company, stated a goal to set a target of installing $25 \%$ of the total biogas plants to be erected in the northern region of the country. Some organizations have constructed domestic biogas plants with their own funds. They are Grameen Shakti (3,664 units installed), BRAC etc. to name a few private organizations.

Biogas plants construction in Bangladesh is shown in figure 3. Graph details:

In 2006- Total biogas plants installed $=206$

In 2007- Total biogas plants installed $=2116$

In 2008- Total biogas plants installed $=2648$

In 2009- Total biogas plants installed $=4459$

In 2010- Total biogas plants installed $=4800$

In 2011- Total biogas plants installed $=5049$

In 2012- Total biogas plants installed $=5555$

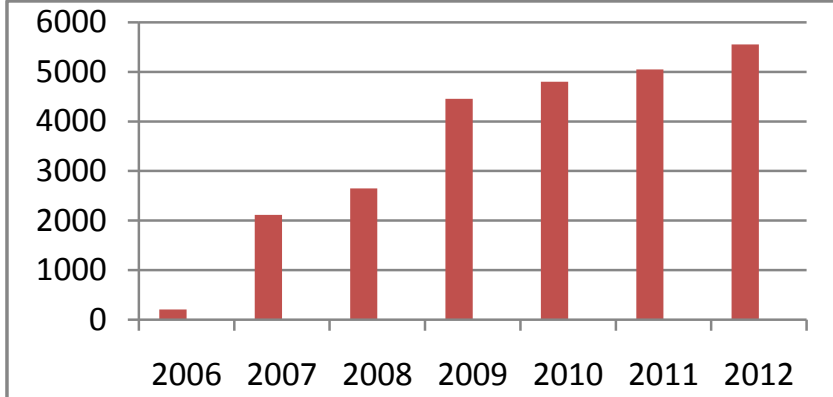

Figure 3. Biogas Plants Construction in Bangladesh under National Domestic Biogas and Manure Programmed (NDBMP)

The technical assessment of the energy potential of biogas assumes that conversion of waste to biogas is $47 \mathrm{~m}^{3} /$ ton from cattle manure and $200 \mathrm{~m}^{3} /$ ton from chicken waste and that biogas consists of $50 \%$ methane.

The biogas plant is assumed to have a reciprocating engine efficiency of $50 \%$ and capacity of $10,000 \mathrm{kWh} / \mathrm{btu}$. The technical potential results are shown in table 6 [14].
Table 6. Biogas Technical Potential

\begin{tabular}{|c|c|c|c|c|}
\hline & \multicolumn{2}{|c|}{$\begin{array}{c}\text { Technical Potential } \\
\left(\mathrm{MWh}^{*}\right)\end{array}$} & \multicolumn{2}{c|}{$\begin{array}{c}\text { Estimated Capacity } \\
\text { Potential }\end{array}$} \\
\hline Division & $\begin{array}{c}\text { Commercial } \\
\text { Cattle and } \\
\text { Buffalo }\end{array}$ & $\begin{array}{c}\text { Commercial } \\
\text { Fowl and } \\
\text { Duck }\end{array}$ & $\begin{array}{c}\text { Commercial } \\
\text { Cattle and } \\
\text { Buffalo }\end{array}$ & $\begin{array}{c}\text { Commercial } \\
\text { Fowl and } \\
\text { Duck }\end{array}$ \\
\hline Barisal & 1,989 & 16,189 & 45 & 370 \\
\hline Chittagong & 11,364 & 69,243 & 259 & 1,581 \\
\hline Dhaka & 18,452 & 188,138 & 421 & 4,295 \\
\hline Khulna & 11,095 & 26,983 & 253 & 616 \\
\hline Rajshahi & 15,999 & 33,193 & 365 & 758 \\
\hline Sylhet & 1,383 & 18,946 & 32 & 433 \\
\hline Total & 60,282 & 352,692 & 1,376 & 8,052 \\
\hline
\end{tabular}

*Based on a heat rate of $10,000 \mathrm{btu} / \mathrm{kWh}$.

***Determined by assuming a efficiency of $50 \%$.

\subsection{Hydro Power}

Kinetic energy from streaming or perishable water is exploited in hydropower plants. Hydropower plants are classified into two categories: Large (>10 MW) and Small ( $<10 \mathrm{MW}$ ) [1]. On average, 1.4 trillion cubic meters of water flows in Bangladesh per year and the annual average rainfall is $2,300 \mathrm{~mm}$, which varies from $1,200 \mathrm{~mm}$ in the north-west to $5,800 \mathrm{~mm}$ in the northeast [16]. Recently, a $230 \mathrm{MW}$ hydro power generation plant was set up in Karnaphuli, Rangamati [17]. It is the only hydro station in Bangladesh and is operated by BPBD. Micro and mini hydropower plants have limited potential in Bangladesh with the exception of those in Chittagong and the Chittagong hill tracts region.

\subsection{Geothermal Energy}

Geothermal energy is a very powerful and efficient way to extract renewable energy from the earth through natural processes. This can be performed on a small scale to provide heat for a residential unit or on a very large scale for energy production through a geothermal power plant. It is cost effective, reliable and environmentally friendly but it has previously been geographically limited to areas near tectonic plate boundaries. With this technology, the steam and hot water produced inside the earth's surface can be used to generate electricity [18]. Bangladesh has various locations for harnessing geothermal resources. Geothermal energy is generated about 4000 miles beneath the surface, in the earth's core. The process takes place due to the slow decay of radioactive particles generating the, high temperatures needed to produce steam. About 10,716 MW of geothermal energy is generated in total in 24 countries worldwide [1]. The northern districts of Bangladesh show the prospect of exploring geothermal resources. As the demand for electricity in urban as well as in rural areas is increasing, but our production of electricity is not. The rural demand for electricity can be covered by the production of electricity through geothermal energy. A private company Anglo MGH Energy has initiated a project to set up the country's first 200 MW electricity generation plant from geothermal sources close to Saland in Thakurgaon district. 


\subsection{Tidal Power}

Tidal power is a form of hydropower that converts the energy of tides into electrical power. As tides are more predictable than wind and sunlight, tidal energy can easily be generated from the changing sea levels. Dams or barrages with water turbines can be placed diagonally in a river's mouth or inlets to generate electricity from the motion of tides. The coast of Bangladesh has a tidal rise and fall from 2 to 5 meters. Among these coastal areas, Sandwip, which experiences 5-meter tidal waves, has the best prospect in generating tidal energy. Moreover, according to existing literature, Bangladesh can generate tidal power from these coastal tidal resources by applying low head tidal movements and medium head tidal movements. Low head tidal movements use tides of height from $2 \mathrm{~m}$ to $5 \mathrm{~m}$ in areas like Khulna, Barisal, Bagerhat, Satkhira and Cox's Bazar regions. In contrast, medium height tidal movements use more than $5 \mathrm{~m}$ high tides which are available in Sandwip [11]. So, geothermal can be a great source of energy for electricity generation in Bangladesh.

\subsection{Ocean Wave Energy}

Ocean wave energy is generated directly from waves in oceans. It is another viable type of renewable energy which helps to decrease the harmful emissions of greenhouse gases associated with the generation of power. It has the potential of being a significant source of electricity in Bangladesh. Though the main purpose of ocean wave energy plants is to generate electricity, they can also be used for pumping water, water desalination etc. The oscillating water column method is technically feasible and is becoming economically attractive for this purpose in many countries.

This type of wave energy harnessing device is being commissioned by several countries such as the U.K (500 $\mathrm{kW})$, Ireland (3.5 MW), Norway (100 kW) and India (150 $\mathrm{kW})$ etc. Bangladesh has the potential for harnessing ocean wave energy from the Bay of Bengal [1].

\section{Calculation of Total Power}

The individual power equations and total power equation are given below [2].

Solar power, $\mathrm{P}_{\text {solar }}=($ Area per sq- $\mathrm{ft} \times$ watts per sq- $\mathrm{ft})(2)$

Wind power, $\mathrm{P}_{\text {wind }}=(1 / 2) \times \rho \times \mathrm{A} \times \mathrm{V}^{3}$

Where,

$A=$ Area perpendicular to the direction of flow $\left(\mathrm{m}^{2}\right)$

$\mathrm{V}=$ Wind velocity $\left(\right.$ in $\mathrm{ms}^{-1}$ )

$\rho=$ Density of air which is about $1.2 \mathrm{Kgm}^{-3}$

Biogas generator power, $\mathrm{P}_{\text {biogas }}(\mathrm{W})=$

$50 \%$ of 100 kilograms per day animal waste $\times 1000$

2 kilograms animal waste per $\mathrm{kWh} \times 5$ hours operation a day per year

Hydro power, $\mathrm{P}_{\text {hydro }}(\mathrm{W})=\mathrm{H} \times \mathrm{Q} \times \mathrm{g} \times 1000$
Where,

$\mathrm{H}=$ Gross water head (in meter)

$\mathrm{Q}=$ Flow of water $\left(\right.$ in $\left.\mathrm{m}^{3} / \mathrm{sec}\right)$

$\mathrm{g}=$ Gravitational acceleration, i.e. $9.81\left(\right.$ in $\left.\mathrm{ms}^{-2}\right)$

Therefore, total power:

$$
\mathrm{PT}(\mathrm{W})=\mathrm{P}_{\text {solar }}+\mathrm{P}_{\text {wind }}+\mathrm{P}_{\text {hydro }}+\mathrm{P}_{\text {biogas }}
$$

\section{Global Scenario of Renewable Energy}

Based on Renewable Energy Policy Network for the $21^{\text {st }}$ century, renewable contributed $19.2 \%$ of humanity's global energy consumption and $23.7 \%$ to their generation of electricity in 2014 and 2015, respectively [19]. This energy consumption is divided with $8.9 \%$ coming from traditional biomass, $4.2 \%$ as heat energy, $3.9 \%$ from hydroelectricity and $2.2 \%$ is electricity from wind, solar, geothermal and biomass. Worldwide investments in renewable technologies amounted to more than US\$ 286 billion in 2015, with countries like China and the United States heavily investing in wind, hydro, solar and befouls. Globally, there are an estimated 7.7 million jobs associated with the renewable energy industries, with solar photovoltaic being the largest renewable employer [19]. Solar PV is a key technology for capturing the benefits namely having no waste, no moving parts, no emissions, less transportation costs, not requiring water during power production and no adverse effects on the environment [20].

Renewable power generating capacity saw its largest annual increase ever in 2016, with an estimated 161 gigawatts (GW) of capacity being added. The world continued to add more renewable power capacity annually than it added (net) capacity from all fossil fuels combined. In 2016, renewable accounted for an estimated $62 \%$ of net additions to global power generating capacity [19].

\section{Conclusions}

In this paper, the present scenario of renewable energy sources in Bangladesh is shown very clearly and coherently. The compendium of this paper demonstrates that there is a great opportunity for Bangladesh to meet its overall power demand by utilizing its available renewable properly. If it can make the best use of its available renewable energy sources then it is possible to extract the load-shedding problem from the country. As a result, this is the high time to look forward and work with these renewable energy fields to produce electricity rather than depending wholly on conventional method. The government has already made an endeavor to overcome the power crisis problem in Bangladesh. More importance should be given on renewable such as solar energy as it is the emerging renewable energy sector in Bangladesh which has potential to meet the majority of the energy and power demand of country's population. Other renewable energy sources can also play a vital role to meet our daily power demand. With the help of 
these resources, Bangladesh can generate electricity and may able to meet the expected power demand in the future. The government and the private sector should work hand in hand to emphasize more on renewable energy sources to produce electricity to solve the power crisis problem in Bangladesh. A brief description of the global scenario of renewable energy is also presented in the paper. As the stock of fossil fuel is decreasing day by day, more emphasis should be given on renewable energy sources to meet global power demand. This paper is the first step to develop a completely uninterrupted power flow nationally as well as globally by making the best use of available renewable energy sources to harness clean energy for electricity and to protect the environment.

\section{ACKNOWLEDGEMENTS}

The authors would like to acknowledge the support and encouragement of Department of Electrical and Electronics Engineering, IUBAT-International University of Business Agriculture and Technology.

\section{REFERENCES}

[1] Md. Saydur Rahman, S.K Saha, Md. R.H Khan, U.H, SMH Chowdhury. 2013. "Present situation of Renewable Energy in Bangladesh: Renewable Energy Resources Existing in Bangladesh" Global Journals Inc (USA).

[2] Mohammad Hossain. 2015. "Achieving Sustainable Energy Targets in Bangladesh" The Magazine of the United Nations.

[3] "Power System Master Plan 2016 Summary" Power Division, Ministry of Power, Energy and Mineral Resources Government of the People's Republic of Bangladesh http://powerdivision.portal.gov.bd/sites/default/files/files/po werdivision.portal.gov.bd/page/4f81bf4d_1180_4c53_b27c 8fa0eb11e2c1/\%28E\%29_FR_PSMP2016_Summary_revise d.pdf.

[4] Md. Alam Hossain Mondal. "Implication of Renewable Energy Technologies in the Bangladesh Power Sector: Long-Term Planning Strategies".

[5] "Target to Generate 2,000 MW Renewable Energy in 2021", http://www.theindependentbd.com/printversion/details/3143
[6] Md Niaz Murshed Chowdhury. 2015. "Present Scenario of Renewable Energy and Non Renewable Energy Sources in Bangladesh: A Compact Analysis" Business and Economics Journal.

[7] M. Hussain. 1987. "Bangladesh Energy Resources and Renewable Energy Prospects".

[8] Md. Abu Bakr Siddique and S. M. Rezaul Karim. 2017. "Modeling of Double Diode Solar Photovoltaic Module using Matlab" International Journal of Computer Applications 179(7): 4-10.

[9] Mazharul Islam. 2008. "Renewable Energy Prospect and Trends in Bangladesh".

[10] “Bangladesh Power Development Board"http://www.bpdb.g ov.bd/bpdb/index.php?option=com content \&view=article\&i $\mathrm{d}=26$.

[11] Md. Habib Ullah, T. Haque \& Md. M. Hasib. "Current Status of Renewable Energy Sector in Bangladesh and a Proposed Grid Connected Hybrid Renewable Energy System".

[12] Khairul Anam and H. A. Bustami. "Power Crisis \& Its Solution through Renewable Energy in Bangladesh".

[13] M. Rofiqul, M. Rabiul, M. R. A. Beg. 2008. "Renewable Energy Resources and Technologies Practice in Bangladesh".

[14] SREDA- Sustainable and Renewable Energy Development Authority. 2015.

[15] U. Rehling, "Small biogas plants, sustainable energy systems and management (SESAM), University of Flensburg, Germany, 2001.

[16] A. K. Azad. 2011. "A Review on Renewable Power Sources: Prospects of Bangladesh and Scotland," EBook, St. Andrew's University, Scotland, UK.

[17] "Development of Renewable Energy in Bangladesh" http://www.thedailystar.net/development-of-renewable-ener gy-in-bangladesh-49670.

[18] I.B. Fridleifsson, R.B, E.H, John. W.L, A.R and L.R. 2008. "The Possible Role and Contribution of Geothermal Energy to the mitigation of Climate".

[19] REN21-Renewable Energy Policy Network for the $21^{\text {st }}$ Century.

[20] Md. Abu Bakr Siddique, M.T. Hoque, T.S. Ullah, R.H. Sagor, Md. S. Ullah. 2015. "Study of PV Implementation for Electricity Generation in Bangladesh" Green Energy and Technology (ICGET), $3^{\text {rd }}$ International Conference on, IEEE, pp. 1-5. 